\title{
Demonstrate the Capacity, Vulnerability and Community Based Disaster Risk Management Scenario of the vulnerable Groups in the Coastal Belt Area Dacope and Chalna in Khulna District of Bangladesh
}

Pronab Kumar Debnath ( $\nabla$ debnath1601560@stud.kuet.ac.bd )

Research

Keywords: CBDRM, Vulnerability, Disaster, Cyclone in Bangladesh

Posted Date: May 28th, 2020

DOI: https://doi.org/10.21203/rs.3.rs-30111/v1

License: (c) (i) This work is licensed under a Creative Commons Attribution 4.0 International License. Read Full License 


\section{Abstract}

Cyclones, floods and salinity are the most common hazards in the coastal zone of Bangladesh. The Dacope and Chalna are the coastal zones located in the south-western region of the country which has the experience to face devastating disasters. There are mentionable positive changes seen in the area since 2004. Despite that, there are many vulnerable peoples in the region. This study has been conducted to demonstrate the capacities \& vulnerabilities and community-based disaster risk management of the area. The data and information have been collected via stakeholder consultation, literature study, and field visits. There are many peoples live on the shore and roadside. The illiteracy, lack of negotiation, lack of cyclone shelters and its capacity, corruption in relief, etc. made them vulnerable. The good social bonding, indigenous knowledge, experience, different volunteer groups have been found as their capacities. They use different measures for disaster risk management.

\subsection{Introduction}

Bangladesh is fighting with disaster since its birth! Almost in every year, it is facing both natural and manmade disasters. Every disaster brings tragedy for the country since its outset! Within the short span of little more than one year, the people of Bengal were faced with natural disasters, bloody repression, and civil war (Chen, 1973). Not a decade has passed since then that Bangladesh does not face any disaster.

Cyclone, storm surge, flood, drought, riverbank erosion, earthquake, and salinity are the common natural calamities (hazards) of Bangladesh. All these hazards do not hit all over the country. It has some regionbased tendencies. For example, salinity is a hazard for south-western people but not for northern. Cyclones and floods are the most common and terrible in the country. Flooding covers averagely $20 \%$ of the geographical area of Bangladesh in every year (Rokonuzzaman and Debnath, 2017). The total number of natural disasters that occurred between 1985 and 2009, floods are accounted for $40 \%$ of that (Kabir and Hossain, 2019).

Another massive damage occurs by the cyclone. In every year, there are eighty tropical cyclones occurred around the globe and among these about four forms in the Bay of Bengal (Crane, 1988). During the last couple of decades, these have been responsible for causing death to numbers of people, considerable loss to agriculture, and damage to infrastructure in the coastal area (Karim, 1995). The coastal areas of Bangladesh are subjected to damaging cyclones almost every year. They generally occur in early summer (April-May) or late rainy season (October-November) (Khan, 2017). It has been observed throughout the long period that death toll due to almost the same category of cyclones is gradually reducing in the coastal belt of Bangladesh (Khan, 2017). For instance, the death toll during Cyclone Sidr 2007 and Aila 2009 were 4,234 and 197 whereas cyclone in 1970 and 1991 were 500,300 and 138,958 respectively (Khan, 2017). This is a good sign and gives some positive messages about the disaster management of the country. 
The coastal belt is situated in the south-western part of Bangladesh. This coastal zone consists of 19 districts and its area is $47,201 \mathrm{sq}$. $\mathrm{km}$. There are $62 \%$ of the land of the coastal zone having an elevation of up to three meters and 86\% up to five meters (MoWR 1999b; Coastal Zone Policy, 2005; Nazem and Mahboob, 1992). After 2000, there are twelve massive cyclones hit in the coastal zones. Among which six (50\%) storms occurred in the last five years. Among these twelve, the country has been faced with devastating cyclone 'Sidr' in November 2007, and 'Aila' in April 2009 (Ahmed, 2010). Salinization is another big problem in the area after the cyclone. According to the Intergovernmental Panel on Climate Change (IPCC) 2001, coastal area of Bangladesh may go under water by 2050 ('Bagchi et al, 2019).

In this circumstance, this study has been conducted on a particular coastal area (Dacope Upazila) of Bangladesh. The field visiting and data collection has been performed between September 2018 to April 2019. The Dacope Upazila (Sub District of the Khulna District, Bangladesh) has been selected as the study area. More specifically the 'Dacope' and 'Chalna', these two unions (Chalna is municipality) have been picked up for the study. The main objectives behind the study were (i) to demonstrate the capacity and vulnerability of the vulnerable groups and (ii) present scenario of community-based disaster risk management of the area. This study has been taken up recent snapshot of hazards, disaster risks, preparedness, awareness, cyclone shelters, indigenous knowledge to disaster management, vulnerability, root causes \& dynamic pressure of vulnerability, and institutional \& other capacities of the local people to inhibit disaster, they are faced.

Dacope is an Upazila of Khulna District, Bangladesh. It has an area of $991.57 \mathrm{~km}^{2}$ and located in between $22^{\circ} 24^{\prime}$ and $22^{\circ} 40^{\prime}$ northern latitudes and $89^{\circ} 24^{\prime}$ and $89^{\circ} 35^{\prime}$ east longitudes (Dacope Upazila, 2015). According to Statistics, (2013) the total population of the Upazila is 1,52,316 and it has 9 Unions and 1 Municipality. The Chalna is only one municipality of the Dacope Upazila and Dacope is also a Union along with other unions of the Dacope Upazila. According to the Banglapedia website, the Dacope union has a total of 4,101 acre land, and 7,280 populations with a $56.61 \%$ literacy rate. In the Chalna, there are 29,774 populations and total area is 11,093 acre along with $53.05 \%$ literacy rate.

\subsection{Methodology}

First, it was studied and literature reviewed about the disaster in the coastal belt area of Bangladesh. Then the study area was selected. Then vulnerable groups of the area were selected. The study was conducted only the selected vulnerable groups in the area. Based on secondary data and field visits, the questionnaires were formed. After that, contacted with different Government \& Non-Government organizations and fixed the date of field study (for data collection survey). The field study was performed to collect data and information. The data and information were analyzed and decorated. The results were reviewed by the team members and experts. Finally, the result was presented. The particular details are given in the following section.

2.1 Study Area Selection: The Dacope Upazila was selected as the study area. It is an Upazila of the Khulna district of Bangladesh. Dacope is adjacent to the Mangrove forest Sundarban ('Bagch et al., 
2019). This Upazila consists of 9 unions and one municipality. Among these nine unions and one municipality, one union (Dacope) and municipality (Chalna) were selected to conduct this study. The map (from Google Map) of the study area is given in the following Fig. 1.

Figure 1: (a) Map of the country and district Khulna (b): the study area Dacope and Chalna

2.2 Factors Influencing to Select the Study Area: The following factors have been influenced to select this study area:

1.

This is the disaster prone area

2.

It is a coastal belt area

3 .

It has a long history of facing disaster

4.

There are different community based programs which have been conducted in last two decades in this area

1.

2.3 Data Source Selection and Collection of Data \& Information: Data and information have been collected from primary and secondary sources. The newspapers, The primary data \& information has been collected by household survey, round meeting (Uthan boithak) with stakeholders, meeting with GO \& NGO's officers, and discussion with people's representatives. Preselected questionnaire was used. The questionnaire covered personal information, hazard list, hazard intensity and frequency, people's preparation; state of housing, shelter facilities in disaster period, sanitation, nutrition condition, and relief etc. Most of the respondents (for questionnaire survey) were women of the household and they were above 30 years old. Finally, identifying different existing (and previously also) projects, programs, and policies address their needs, through targeted interventions or prevention and mitigation of potential adverse impacts were addressed.

2.

2.4 Formation and Representation of Result: After the collection of data and information, the study team sat together and discussed it. The different data were analyzed and represented by word processing and spreadsheet (M/S Excel) software. From dataset different profile like hazard profile, vulnerabilities and capacities were represented by the different tables. The relation among stakeholders, Governmental \& Non-Governmental organizations were presented by a Venn diagram. The causes behind their vulnerability, unsafe condition, and disaster risk were represented by Crunch Model.

The schematic diagram of methodology is given in the following Fig. 2.

\subsection{Result And Discussion}


The findings from the study have been represented in this section. The result and discussion section have covered hazards profile, capacities of the community, vulnerability, existing risks, indigenous knowledge; community response in disaster preparedness, and measures they practice in hazard time. The different models and methods have been used to represent the result.

3.1 Hazard Profile: There are different types of hazards attacks in this coastal belt (Dacope and Chalna). The names of hazards were found by stakeholder discussion and questionnaire surveys of these areas. The most common hazards in the area found are discussed and hazard profile is shown in Fig. 3.

1. Cyclone: The cyclone Sidr, Aila, Nargis, etc. hit in the area. Almost every year, cyclone and storm surge attacks in the area. In the last of March to May and late rainy season (October-November), the cyclones hit in the area.

2.

Flood and Heavy rain: Though this area faced floods of 1987, 1988, 1998, and 2004 (Khan, 2008), the last decade the community did not face any devastating floods. "Heavy rain did not make any flood in the last 5 to 6 years," the community said. The heavy rain creates a problem by inundated the housing, roads, and agricultural fields.

3.

Salinity: For salinity problems, only two crops are cultivated in a year. In rainy season when salinity is decreased, in that time paddy is cultivated and during cold to summertime, vegetables, and fruits (watermelon, cucumber, ladies' fingers, tomato, banana, etc.) are cultivated.

4.

Thunderstorm: It is another hazard for the local people of the area. They face thunderstorms every year. The community is less aware of the hazard.

5.

Earthquake: It happens unlikely in the area.

3.2 Capacity and Vulnerability of the Community: The capacity and vulnerability of the community have been assessed by CVA method which is a simple matrix method to show people's situation of vulnerability and capacities. It has three categories are:

Physical or Material

Social or Organizational

Motivational and Attitudinal

Based on the data and information the vulnerable people are divided into two main groups are:

\section{Vulnerable group 1}


They have no resources, located in road side and river bank or in the Governmental housing project, depend upon daily income.

\section{Vulnerable group 2}

They have some resources, good income level, located comparatively high land, and live in their housing, but they are vulnerable caused of infrastructure condition, absence (or lower capacity) of cyclone shelters, lower education and access to information. The vulnerabilities and capacities of the community are given in the following Table 1. 
Table 1

Vulnerabilities and Capacities of the Community of Dacope and Chalna

\section{CATEGORIES VULNERABILITIES CAPACITIES}

Physical or Natural calamities like Cyclone, Flood; Adequate amount of paddy production; Material

Poor infrastructure;

Lack of medical service like very limited hospitals and their capacities;

High levels of unemployment;

Unplanned polders;

Numbers of women and children;

Low numbers of income people;

Scarcity of potable water; etc.

Social or Organizational

Corruption in relief distribution;

Absence of people's representative in time (MP, Chairman etc.);

Less numbers of volunteer organizations; etc.
Fish availability;

Developed communication system;

Experience of disaster management;

Numbers of youths; etc.
Limited land per capita; Leadership skills of people;

Indigenous knowledge;

Peoples are organized;

Adequate numbers of NGO

Women groups;

Social capital; and

Adaptive strategy.

Cooperating;

Good ideological;

Social networking;

Lack of negotiation capability; and

Over confidence; etc.
Ability to work together (all religion and opinions) during disaster; and

Positive attitude to women, children and elders.

3.3 Disaster Risk in the Community: The community of Dacope and Chalna actively are in disaster risk. Natural hazards are major in numbers and frequent, they face regularly. Though there was no devastating disaster in recent years, there are high risks to disaster caused of their socioeconomic condition. Most of the families have 4 to 8 members and income members are only $1-2$ in a family. Almost $80 \%$ of respondents of the questionnaire survey found educated up to the primary level. The majority numbers of people in the area were found daily labors, farmers, or small traders. Income levels of households are in between 6000 to 8000 in BDT (75-100 US dollars) in a month. There are almost $30 \%$ of housing made with corrugated iron sheets, $60 \%$ with bamboo and local golpata (Nipa Palm which is locally known as 
golpata), and the rest $10 \%$ are with mud house found in a vulnerable group. The sanitation condition was not so bad. Many NGO's and Government initiatives have been developed the sanitation condition. Nevertheless, some households were found in vulnerable groups with no sanitary latrine. Sanitary conditions during the rainy season or heavy rain become very bad. Maximum child and adult also are affected by diarrhea, dysentery, typhoid fever, abdominal pain, etc. Another crisis was the scarcity of potable water. Drinking water has to be fetched from far away or bought to drink of vulnerable groups. The shallow water is brine all these areas. The education level, family members, income level, and numbers of income people in a household are given in the following Fig. 4.

a.

(b) Numbers of Family Members Found of the Respondents of Vulnerable Group b.

(c) Monthly Income (in US Dollar) of the Respondents

C.

(d) Number of Income Members in a Family of the Vulnerable Group

The disaster risk of a vulnerable group of the study area has been modeling by the Crunch Model. According to the model, disaster happens when vulnerable condition meets with hazards. It has been seen that "vulnerability - a pressure that is rooted in socio-economic and political processes - is built up and has to be addressed, or released, to reduce the risk of a disaster" (Oxfam, 2012). In this model, there is three "progression of vulnerability". A brief of the progression of vulnerability is discussed in the following section and the Crunch Model is given in Fig. 5 .

The main unsafe condition has been found in their household condition \& location. Many peoples were found to live on the river bank and roadside. The shelter is made of local bamboo, wood, tin shade, and mud. There was no specific facility found for women, elders, and disabilities. There was no social conflict found, but the unequal representation of women in decision-making processes had been found. These all have been made unsafe for vulnerability.

In the study area, limited cyclone shelter and its capacity, limited numbers of research and analysis with its contribution to Governmental activity, limited to ethical standards in public life, deforestation, rapid migration tendencies that change the social structure, and decline in soil productivity are the dynamic pressure for the area.

Most of the time, development does not reach to the poor. The Governmental negligence, lack of application of the related policies on the socio-economic development, poor men \& women are not allowed to attend Governmental meetings on disaster mitigation \& emergency response preparedness, limited access to power, and economic inequalities between women \& men are the influence for their vulnerability. These points are the root causes of the vulnerability of the group of people in the study area. 
3.4 Community Disaster Risk Management: In the case of vulnerable groups of the area, they did not overcome their vulnerability, but many NGOs and some Governmental institutions are trying to develop the situation. When the cyclone 'Sidr' and 'Aila' attacked, there was no cyclone shelter in the area. Now, there is a cyclone shelter for 2 or 3 union's people.

Some NGOs are providing training, especially for vulnerable women. There is a community health clinic for free health services. The NGO's and local Government has been formed 'local disaster risk management (DRM) team' for the community. Some local institutes are doing well in disaster management in the area. The early warning systems have been updated and are technology-based. The relation (contribution) among different Government \& NGOs, local DRM team, Seed Providing Group (SPG), local institutions, community clinic \& hospital with vulnerable groups are represented by a 'Venn' diagram in the following Fig. 6.

The community practices for the precautions and warnings to protect against disasters are:

-They save seeds for hazard period. Seeds are collected and keep in polybag in dry condition or some family keeps seeds in kolos (vessel) underground.

-They use hybrid and local, both type of seeds.

-Almost every household has their cattle. Cow and got is the major cattle. Hen, swan, and duck are the major poultry in households.

-Peoples save feed for cattle and poultry.

-The peoples of the community are mentally prepared and alert for in the hazard season.

- They have a family bank called 'lokkhir Varar' and they save some money here every day.

-People receive messages or alerts of hazards on television, radio, and mobile phone. They receive messages on mobile from different NGOs.

\subsection{Conclusion}

The numbers of vulnerable groups have been found in these two unions of the Upazila. This study has been brought to the internal scenario of their capacity and vulnerability. The people are well bonded in society. They have long experience to face hazards regularly. Though they do not get the benefit of all Governmental policies, some NGOs are doing well in the area. All these are their capacity. The vulnerable peoples use their indigenous knowledge to save themselves from disaster. They practice some measures to deal emergency period of the hazardous season. Besides these, they are vulnerable to their household pattern and structures. Many of them are live on the shore and along the roadside. Their education level, access to information, consumption of power, lack of opportunity to participate in government meetings, lack of cyclone shelter and its capacity, etc. all made them vulnerable.

\section{Declarations}


Availability of data and materials: data and materials are taken from some website and literature which are cited in the text. No data set has been used.

Competing interests: There is no competing interest. There is only one author written the article and the author does not have any financial or other interest by publishing the article.

Funding: There was no funding organization behind the research. It was a work by volunteering team.

Authors' contributions: Only one author has been completed this research paper. Therefore, all of the same author's contribution.

Acknowledgements: Anzum Tasnuva, Associate professor, IDM, KUET, who provide technical instruction to fulfillment of the work. Subinoy Biswas Nayan (M.Sc. in Civil), Ahmed Raju (PGD in Disaster Management, KUET, help to work as team member.

\section{References}

1. Ahmed, B., I. Kelman, H. K. Fehr, and M. Saha. 2010. Community resilience to cyclone disasters in coastal Bangladesh. Sustainability 8 (8): 805.

2. 10.34104 /ajeit.019.14020

${ }^{1}$ R. Bagchi, M. A. Miah, M. A. Islam, S. A. Bithi, and M. Shamsuzzoha. 2019. Assessment on Climate Change Adaptation: A Study on Coastal Area of Khulna District in Bangladesh, Australian J. of Engineering and Innovative Technology, 1 (6), 14-20. https://doi.org/10.34104/ajeit.019.14020.

3. 10.3329/jesnr.v11i1-2.43384

${ }^{2}$ R. Bagchi, M. Miah, S. Islam, and S. Shil. 2019. Impacts on environmental components of the proposed liquefied petroleum gas bottling and distribution plant at Dacope Khulna in Bangladesh. Environmental Science and Natural Resources, 11 (1-2), 171-181. https://doi.org/10.3329/jesnr.v11i1-2.43384.

4. Chen, L. C. 1973. Disaster in Bangladesh. Oxford University Press, 1973.

5. Coastal Zone Policy. 2005. Ministry of Water Resources. Government of the People's Republic of Bangladesh, Dhaka, Bangladesh.

6. Crane, G. D. 1988. Tropical cyclones: The warning system in Australia, UNDRO News, (Sept- Oct.), Australia.

7. Dacope, Upazila. 2015. Banglapedia.

8. http://en.banglapedia.org/index.php?title=Dacope_Upazila.

9. Kabir, M. H., and M. N. Hossen. 2019. Impacts of flood and its possible solution in Bangladesh. Disaaster advances, 12 (10).

10. Karim, N. 1995. Disasters in Bangladesh. Natural Hazards 11 (3): 247-258.

11. Khan, M. 2017. Issues and challenges of Cyclone Preparedness Programme (CPP) volunteers: the case of CPP, Dacope, Khulna (Doctoral dissertation, BARC University). 
12. Khan, M. S. A. 2008. Disaster preparedness for sustainable development in Bangladesh. Disaster Prevention and Management 17 (5): 662-671.

13. MoWR. 1999. Integrated Coastal Zone Management: Concepts and Issues; A GoB Policy Note. Dhaka: Ministry of Water Resources, Government of Bangladesh.

14. Nazem, N. I., and A. Q. M. Mahboob. 1992. Development of Coastal Region of Bangladesh. In Sharif. A.H.M.R and Kalam, ed. K. M. Elahi, A.K.M.A (ed.), Bangladesh: Geography; Environment and Development, Bangladesh National Geographical Association (BNGA), Dhaka, Bangladesh.

15. Oxfam, G. B. 2012. The disaster crunch model: Guidelines for a gendered options. https://policypractice.oxfam.org.uk/publications/the-disaster-crunch-model-guidelines-for-a-gendered-approach247511.

16. Rokonuzzaman, M., and P. K. Debnath. 2017. Disaster Management, Dhaka, Haque Publication, 2017.

17. Statistics, B. B. O. 2013. District Statistics 2011. Ministry of Planning, Government of The People's Republic of Bangladesh.

\section{Figures}



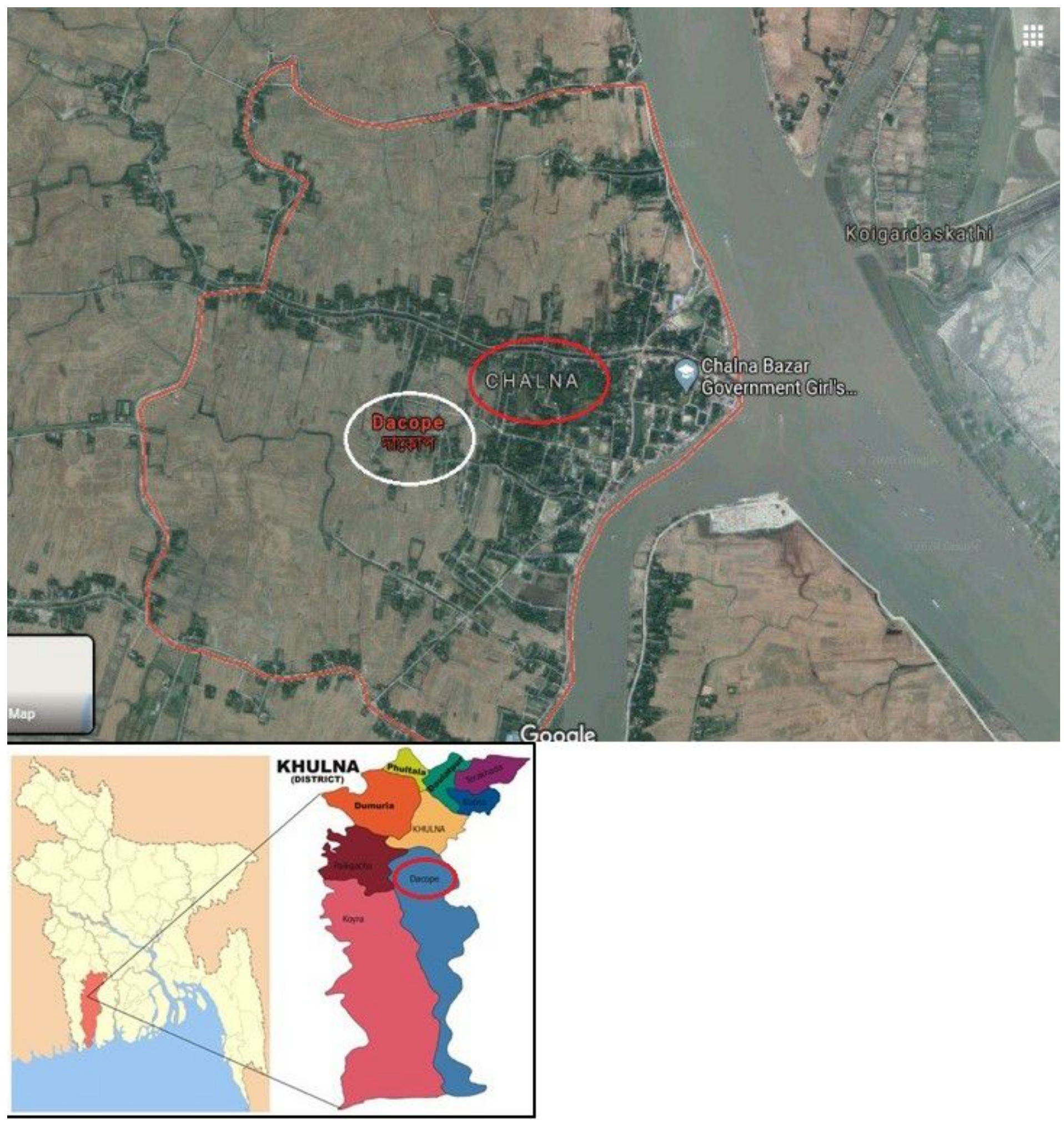

Figure 1

a) Map of the country and district Khulna (b): the study area Dacope and Chalna 


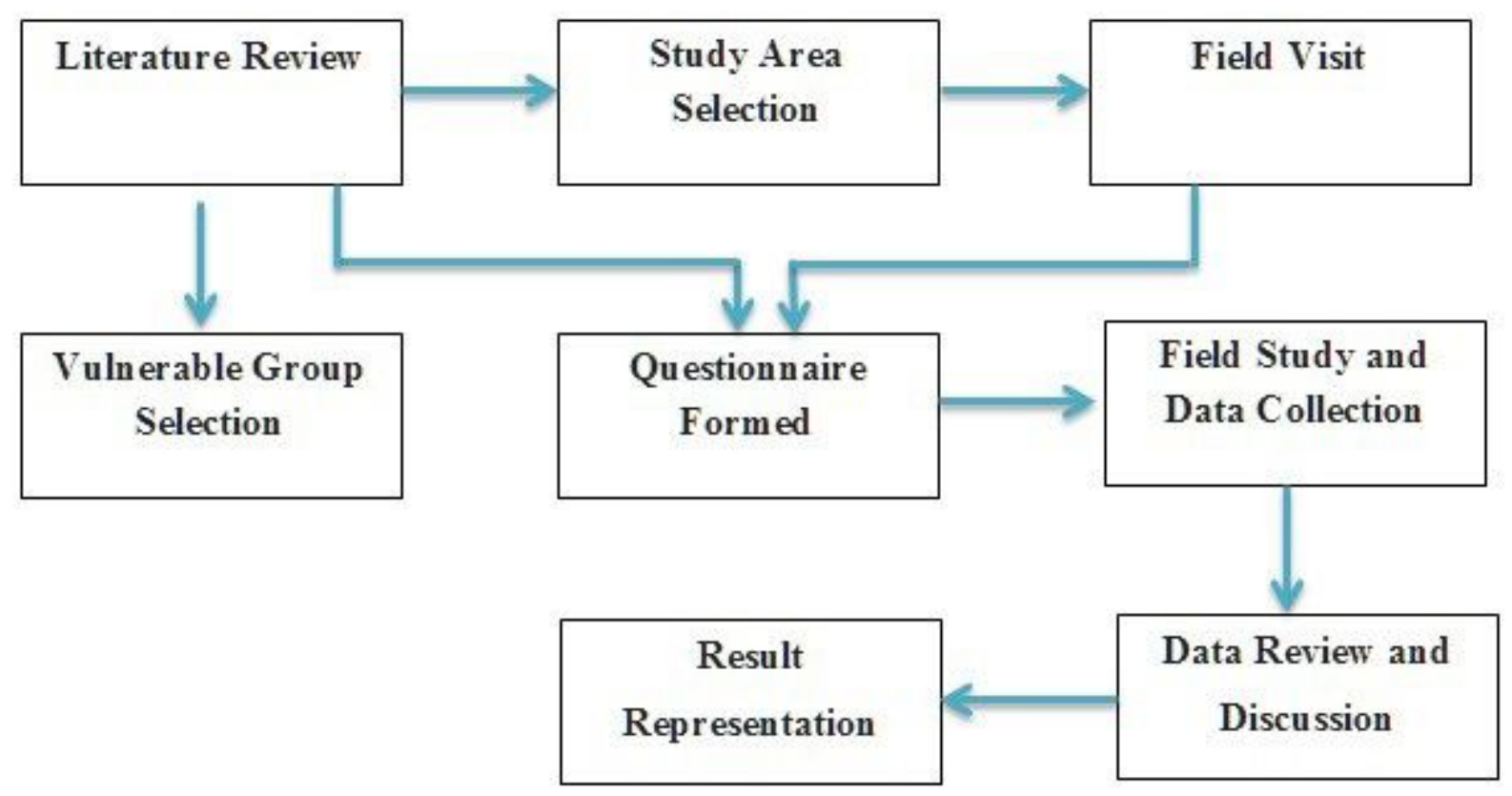

Figure 2

Schematic diagram of methodology of the study

\begin{tabular}{|l|l|}
\hline Enormous & Frequency \\
\hline Long & Magnitude \\
\hline Slow & Duration \\
\hline Limited Small & Speed of Onset \\
\hline C Cyclone O Flood and Heavy rain Salinity & Areal Extent \\
\hline Thunderstorm Earthquake & Fast \\
\hline
\end{tabular}


Figure 3

Hazard profile of the coastal zone of Khulna Bangladesh

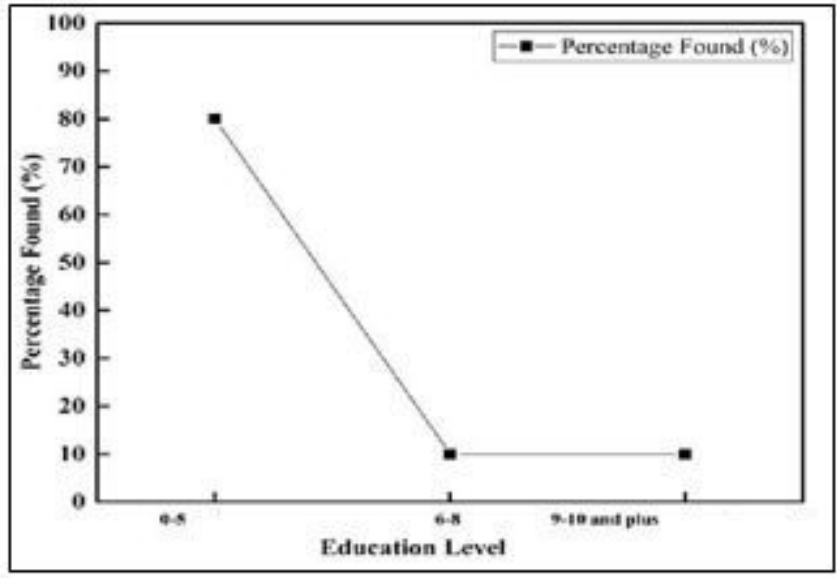

(a)

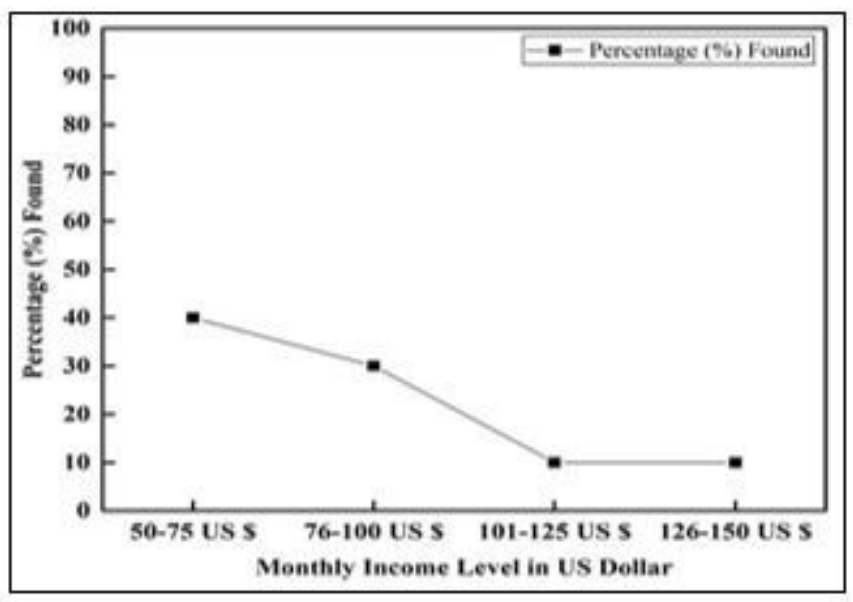

(c)

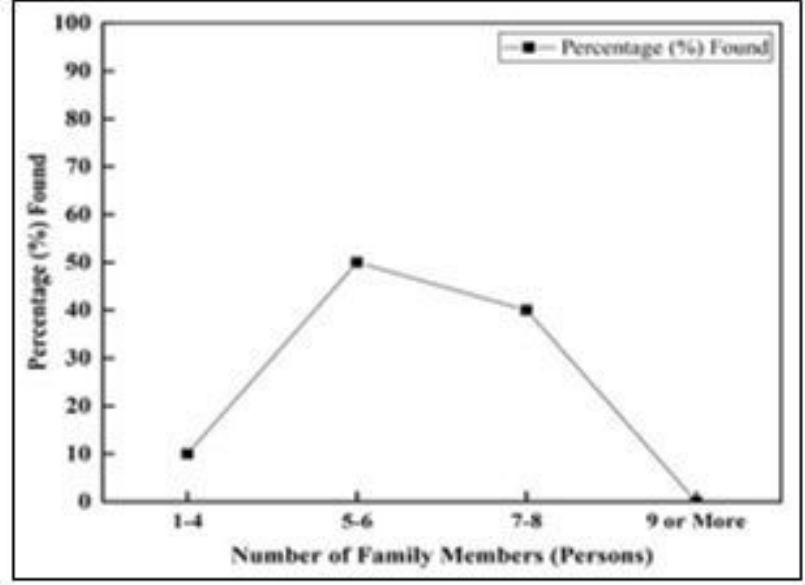

(b)

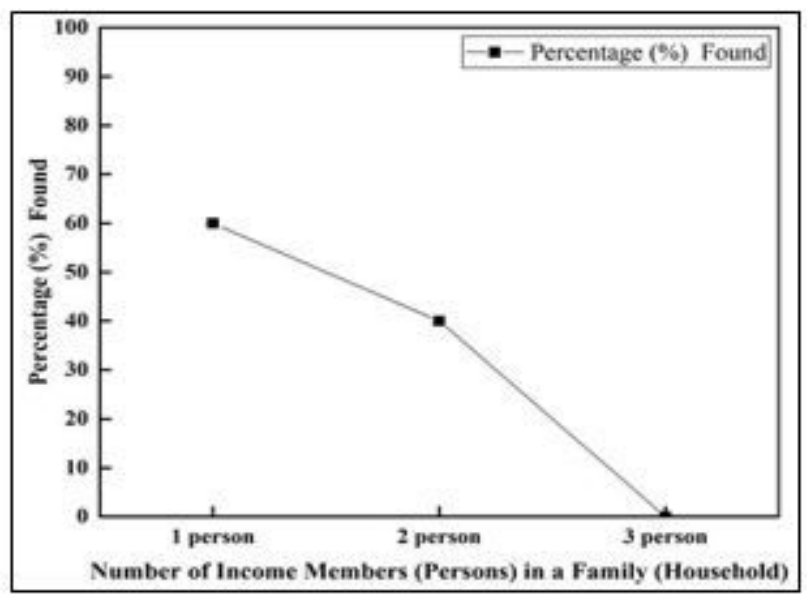

(d)

Figure 4

(a) Education Level Found of the Respondents of Vulnerable Group (b) Numbers of Family Members Found of the Respondents of Vulnerable Group (c) Monthly Income (in US Dollar) of the Respondents (d) Number of Income Members in a Family of the Vulnerable Group 


\begin{tabular}{|c|c|c|c|c|}
\hline $\begin{array}{l}\text { - Negligence } \\
\text { - Lack of policies } \\
\text { - Not allowed to } \\
\text { Governmental } \\
\text { meetings } \\
\text { - Limited access } \\
\text { to power } \\
\text { - Economic } \\
\text { inequalities }\end{array}$ & $\begin{array}{l}\text { Dynamic Pressure } \\
\text { - Limited numbers } \\
\text { of cyclone shelter } \\
\text { and its capacity } \\
\text { - Limited numbers } \\
\text { of research and } \\
\text { analysis } \\
\text { - Limited to ethical } \\
\text { standards in public } \\
\text { life } \\
\text { - Deforestation } \\
\text { - Rapid migration } \\
\text { - Declines in soil } \\
\text { productivity }\end{array}$ & $\begin{array}{l}\text { Unsafe Condition } \\
\text {-Household } \\
\text { condition \& } \\
\text { location } \\
\text { - Facility for } \\
\text { women, elders, } \\
\text { and disabilities } \\
\text { - Low per capita } \\
\text { income } \\
\text {-Unequal } \\
\text { representation of } \\
\text { women in } \\
\text { decision-making } \\
\text { processes }\end{array}$ & $\begin{array}{c}\text { Disaster }= \\
\text { Vulnerability } \\
\text { X } \\
\text { Hazards }\end{array}$ & $\begin{array}{l}\text { Hazards } \\
\text { - Cyclone } \\
\text { - Heavy Rain } \\
\text { - Salinity } \\
\text {-Thunderstorm }\end{array}$ \\
\hline
\end{tabular}

\section{Figure 5}

The disaster risk of the study area presented by the 'Crunch Model'

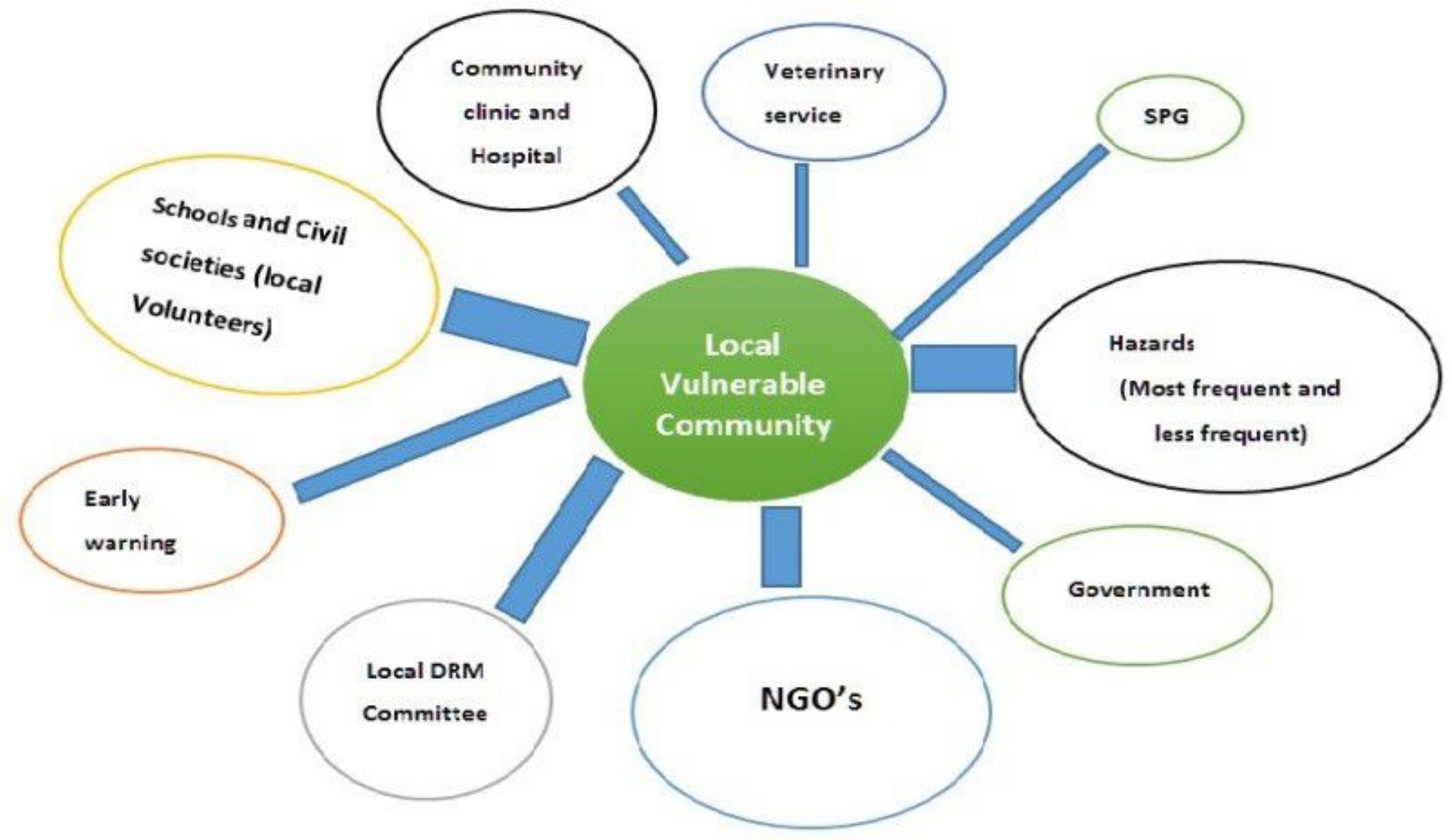

\section{Figure 6}

Venn diagram among different entities of the study area 